Article

\title{
Adsorption of Toxic Zinc by Functionalized Lignocellulose Derived from Waste Biomass: Kinetics, Isotherms and Thermodynamics
}

\author{
Jiatao Dang ${ }^{1}$, Hui Wang ${ }^{2}$ and Chongqing Wang ${ }^{3, *}$ (1) \\ 1 Key Laboratory of New Materials and Facilities for Rural Renewable Energy of Ministry of Agriculture and \\ Rural Affairs, College of Mechanical \& Electrical Engineering, Henan Agricultural University, \\ Zhengzhou 450002, China; dangjt1988@163.com \\ 2 College of Chemistry and Chemical Engineering, Central South University, Changsha 410083, China; \\ huiwang1968@163.com \\ 3 School of Chemical Engineering, Zhengzhou University, Zhengzhou 450001, China \\ * Correspondence: zilangwang@126.com or cqwang1990@zzu.edu.cn
}

Citation: Dang, J.; Wang, H.; Wang, C. Adsorption of Toxic Zinc by Functionalized Lignocellulose Derived from Waste Biomass: Kinetics, Isotherms and Thermodynamics. Sustainability 2021, 13, 10673. https://doi.org/10.3390/ su131910673

Academic Editor: Alessio Siciliano

Received: 27 August 2021

Accepted: 23 September 2021

Published: 26 September 2021

Publisher's Note: MDPI stays neutral with regard to jurisdictional claims in published maps and institutional affiliations.

Copyright: (C) 2021 by the authors Licensee MDPI, Basel, Switzerland. This article is an open access article distributed under the terms and conditions of the Creative Commons Attribution (CC BY) license (https:/ / creativecommons.org/licenses/by/ $4.0 /)$.
Abstract: Heavy metals pollution receives worldwide attention due to great toxicity, significant bio-accumulation and non-biodegradability. Adsorption is a promising technique for removing heavy metals from wastewater. Adsorption of zinc ( $\mathrm{Zn}(\mathrm{II}))$ from aqueous solution was investigated by functionalized lignocellulose derived from fallen leaves. Alkalized lignocellulose (AC), xanthated lignocellulose $(\mathrm{XC})$ and carboxylated lignocellulose (CC) were characterized by Fourier transform infrared spectrum (FTIR), X-ray photoelectron spectroscopy (XPS) and scanning electron microscopy (SEM). The effect of sorbent dosage, solution $\mathrm{pH}$, sorption time and initial $\mathrm{Zn}$ (II) concentration on $\mathrm{Zn}$ (II) sorption was investigated by single-factor experiment. Sorption kinetics, isotherms and thermodynamics were examined to reveal sorption mechanism. The sorption capacity and removal rate remarkably depend on experimental variables. $\mathrm{Zn}$ (II) sorption onto AC, XC and CC is well described by the pseudo second order kinetics and Langmuir isotherm. The sorption process is fast, reaching sorption equilibrium at $30 \mathrm{~min}$. The maximum sorption capacity of $\mathrm{Zn}$ (II) onto CC is $46.49 \mathrm{mg} / \mathrm{g}$, higher than that onto AC, XC and other reported sorbents. Thermodynamic parameters indicate that $\mathrm{Zn}$ (II) sorption is a spontaneous process. Sorption mechanism is majorly attributed to surface complexation. This work shows the feasibility of removing toxic $\mathrm{Zn}$ (II) from aqueous solution by locally available biomass, providing a sustainable approach for wastewater treatment.

Keywords: adsorption; chemical modification; heavy metals; waste biomass; wastewater treatment

\section{Introduction}

Heavy metals (HMs) cause a serious threat to ecological system and public health, due to great toxicity, significant bio-accumulation and non-biodegradability [1,2]. HMs in water can be easily taken in by organism and accumulated in animals and human beings via food chain. The accumulated HMs in living tissues and organs results in serious diseases and disorders [3]. Therefore, HMs should be strictly controlled to meet the safe discharge standards. Various techniques are proposed for management of HMs pollution [4,5]. Among these techniques, adsorption is very promising because of the advantages of easy operation, low cost and possibility of metal recovery.

Adsorbents are the key material for adsorption process. Great efforts have been conducted to develop effective adsorbents for HMs. Various advanced materials, such as carbon nanotubes [6], graphene oxide nanocomposites [7] and biopolymer nanofiber membranes [8], have attracting performance for HMs adsorption, but the cost and preparation process significantly limits their real application. The common commercial adsorbents, such as activated carbon and ion exchange resins, are relatively expensive for application [9]. Recently, sorption of HMs by lignocellulosic biomass (LCB) has been the focus of 
considerable studies, and adsorbents derived from waste biomass have been proved to be effective to promote sustainability owing to the renewability, eco-friendliness and low cost of biomass [10,11]. Natural LCB is mainly composed of cellulose, hemicelluloses and lignin, containing various polar groups involving alcohol, aldehyde, carboxylic and ether groups. These groups have ability to donate an electron pair to form complexes with HMs. Most of the adsorption studies have been focused on untreated LCB including persimmon leaf [12], Landoltia punctata and Spirodela polyrhiza [13], Cinnamomum camphora [14] and orange peel [15].

However, natural LCB shows low adsorption capacity and causes negative effects on water such as high chemical oxygen demand, due to the release of soluble organic compounds contained in the materials [16]. Chemical modifications are proposed to reduce soluble organic compounds and/or increase functional groups, which enhances complexation ability to $\mathrm{HMs}$. Biosorption of $\mathrm{Cd}(\mathrm{II}), \mathrm{Cu}$ (II) and $\mathrm{Zn}$ (II) was examined using sodium hydroxide immersed Cymbopogon schoenanthus L. Spreng [17]. Introduction of xanthate and carboxylate groups on porous starch improved $\mathrm{Pb}$ (II) sorption [18]. Modifications of olive tree pruning with nitric acid, sulfuric acid and sodium hydroxide were compared for $\mathrm{Pb}(\mathrm{II})$ sorption, and sodium hydroxide modification gave best performance [19]. Removal of $\mathrm{Pb}$ (II) ions from aqueous solution was investigated using nitric acid pretreated Tephrosia purpurea leaf [20]. Microwave-assisted modification of jute fiber was reported for HMs removal, and the modification removed non-cellulose substances and introducing carboxyl groups [21]. Ultrasound-assisted xanthation of Cinnamomum camphora is optimized for $\mathrm{Pb}$ (II) sorption [22]. Previous studies have proven the effectiveness of modification of LCB for HMs adsorption.

Zinc, as an essential trace element for human health, is vital for physiological functions of tissues and organs. However, excessive zinc causes serious health problems including anemia, nausea, skin irritations and stomach cramps [23]. Zn(II) was used as target toxic metal to evaluate sorption efficiency of the prepared sorbents. To the best of our knowledge, $\mathrm{Zn}$ (II) sorption by chemically modified LCB from waste biomass is investigated in this work. The main objective of this study is to examine the sorption behavior and mechanism of $\mathrm{Zn}$ (II) ion on modified lignocellulose from LCB, specifically (1) to characterize the physicochemical properties of sorbents; (2) to determine the effect of experimental factors including sorbent dosage, solution $\mathrm{pH}$, sorption time and initial $\mathrm{Zn}$ (II) concentration; (3) to reveal sorption mechanism by studying sorption kinetics, isotherms and thermodynamics.

\section{Materials and Methods}

\subsection{Materials}

Samples of waste biomass were locally obtained fallen leaves in Changsha city, China. The samples were washed, dried and ground into $0.3-0.076 \mathrm{~mm}$. All used chemicals were analytical grade. $\mathrm{Zn}$ (II) solution of $1000 \mathrm{mg} / \mathrm{L}$ was prepared by dissolving zinc nitrate hexahydrate in a $1 \mathrm{~L}$ volumetric flask. Zn(II) solutions with different concentration were prepared by serial dilutions. Visual MINTEQ 3.1, a chemical equilibrium freeware for the calculation of metal speciation, solubility equilibria, etc., was used to examine the zinc ion species in aqueous solution.

\subsection{Preparation of Functionalized Cellulose}

Alkali treatment of the waste biomass with $1.0 \mathrm{~mol} / \mathrm{L} \mathrm{NaOH}$ solution was conducted to obtain alkalized lignocellulose (AC). Xanthation of AC assisted by ultrasound was carried out to obtain xanthated lignocellulose $(X C)$. Experimental conditions were $\mathrm{NaOH}$ concentration $1.3 \mathrm{~mol} / \mathrm{L}$, ultrasonic time $72 \mathrm{~min}$ and $\mathrm{CS}_{2}$ dosage $1.5 \mathrm{~mL}$. Carboxylated lignocellulose (CC) was gained by carboxylation modification of AC. Briefly, AC (5 g) was reacted with succinic anhydride $(15 \mathrm{~g})$ under pyridine reflux $(50 \mathrm{~mL})$ for $24 \mathrm{~h}$. The yield of the prepared sorbents was calculated via $M / M_{0}{ }^{*} 100$, where $M$ and is the final and initial mass of cellulose, respectively. 


\subsection{Characterizations}

Fourier transform infrared spectra were recorded using a Nicolet Avatar 360 FTIR spectrometer (Nicolet Magua Corporation, USA) to characterize the functional groups of the sorbents. The surface elements were determined by an ESCALAB 250Xi X-ray photoelectron spectroscopy (XPS; Thermo Electron Corporation, USA), and binding energies were referenced to the $\mathrm{Cls}$ peak at $284.6 \mathrm{eV}$. A Quanta FEG 250 scanning electron microscopy (SEM; FEI, USA) was used to determine surface morphology of sorbents.

\subsection{Sorption Experiments}

$\mathrm{Zn}$ (II) sorption was evaluated in an SHA-B thermostatic oscillator (Changzhou Aohua Instrument Co. Ltd., China) at stirring speed of $150 \mathrm{rpm}$. Experimental conditions were fixed at $200 \mathrm{mg} / \mathrm{L} \mathrm{Zn(II)} \mathrm{solution,} \mathrm{sorption} \mathrm{time} 30 \mathrm{~min}$ and room temperature $\left(30 \pm 2{ }^{\circ} \mathrm{C}\right)$. The effect of sorbent dosage (2-32 g/L), $\mathrm{pH}(1-7)$, sorption time (0-90 min) and initial concentration (50-1200 mg/L) on Zn(II) sorption was investigated. After sorption, Zn(II) concentration was determined by inductively coupled plasma-atomic emission spectrometry (ICP-AES, Perkin Elmer Optima 5300 DV). The removal rate and sorption capacity of $\mathrm{Zn}$ (II) were calculated by Equations (1) and (2).

$$
\begin{gathered}
R=\frac{\left(C_{0}-C_{e}\right)}{C_{0}} \times 100 \\
Q=\frac{\left(C_{0}-C_{e}\right) V}{m}
\end{gathered}
$$

where $R$ is the removal rate, \%; $Q$ is the sorption capacity, $\mathrm{mg} / \mathrm{g} ; C_{0}$ and $C_{e}$ is the initial and equilibrium concentration of $\mathrm{Zn}(\mathrm{II}), \mathrm{mg} / \mathrm{L} ; V$ is the volume of solution, $\mathrm{L} ; m$ is the mass of sorbent, $g$.

To provide better understanding of sorption process, sorption kinetics, isotherms and thermodynamics were investigated employing multiple models. The pseudo first order, pseudo second order and Weber-Morris kinetic models are shown as Equations (3)-(10).

$$
\begin{gathered}
\ln \left(Q_{e}-Q_{t}\right)=\ln Q_{e}-k_{1} t \\
\frac{t}{Q_{t}}=\frac{1}{k_{2} Q_{e}^{2}}+\frac{t}{Q_{e}} \\
Q_{t}=k_{i} t^{0.5}+C_{i}
\end{gathered}
$$

where $k_{1}\left(\mathrm{~min}^{-1}\right)$ and $k_{2}(\mathrm{~g} /(\mathrm{mg} \mathrm{min}))$ are the rate constant of pseudo first order model and pseudo second order model; $t$ is the contact time; $Q_{t}(\mathrm{mg} / \mathrm{g})$ and $Q_{e}(\mathrm{mg} / \mathrm{g})$ are the sorption capacity of $\mathrm{Zn}$ (II) at time $t$ and equilibrium sorption capacity.

The Langmuir and Freundlich isotherm models are shown as Equations (6) and (7).

$$
\begin{gathered}
\frac{C_{e}}{Q_{e}}=\frac{b}{Q_{m}}+\frac{C_{e}}{Q_{m}} \\
\log Q_{e}=\log K_{F}+\frac{1}{n} \log C_{e}
\end{gathered}
$$

where $C_{e}(\mathrm{mg} / \mathrm{L})$ is the equilibrium concentration of $\mathrm{Zn}(\mathrm{II}) ; Q_{e}(\mathrm{mg} / \mathrm{g})$ is equilibrium sorption capacity of $\mathrm{Zn}(\mathrm{II}) ; Q_{m}(\mathrm{mg} / \mathrm{g})$ is the maximum sorption capacity; $b(\mathrm{~L} / \mathrm{mg})$ is a constant that relates to the sorption heat; $K_{F}$ and $n$ are Freundlich constants indicating sorption capacity and sorption intensity, respectively.

To examine sorption thermodynamics, the Gibbs free energy change, enthalpy change and entropy change were calculated based on Equations (8)-(10).

$$
\begin{aligned}
\Delta G & =-R T \ln K_{c} \\
\ln K_{c} & =\frac{\Delta S}{R}-\frac{\Delta H}{R T}
\end{aligned}
$$




$$
K_{c}=\frac{Q_{e}}{C_{e}}
$$

where $\Delta G(\mathrm{~kJ} / \mathrm{mol})$ is the Gibbs free energy change; $\Delta H(\mathrm{~kJ} / \mathrm{mol})$ is the enthalpy change; $\Delta S(\mathrm{~J} /(\mathrm{mol} \mathrm{K}))$ is the entropy change; $K_{c}$ is the equilibrium constant; $Q_{e}(\mathrm{mg} / \mathrm{g})$ is the equilibrium sorption capacity; $C_{e}(\mathrm{mg} / \mathrm{L})$ is the equilibrium concentration of $\mathrm{Zn}(\mathrm{II}) ; R$ $(8.314 \mathrm{~J} /(\mathrm{K} \mathrm{mol}))$ is the gas constant; $T(\mathrm{~K})$ is the temperature in Kelvin.

\section{Results and Discussion}

\subsection{Characterizations}

Preparation of functionalized lignocellulose is shown in Figure 1. Major ingredients of raw biomass are cellulose, hemi-cellulose and lignin [24]. Alkali treatment is conducted to extract cellulose by partly removing hemi-cellulose, lignin and low molecular weight matters. The reactivity and accessibility of hydroxyl groups in cellulose molecules can be improved [25]. Xanthation and carboxylation of AC are carried out to further modify cellulose derived from biomass, and they induce more functional groups for metal sorption [26,27]. It should be noted that complete extraction of cellulose from LCB using the alkalization process is not possible, and therefore functionalization reaction with hemicellulose and lignin cannot be completely ruled out. The yield of AC, XC and CC is $81.7 \%$, $94.2 \%$ and $97.6 \%$, respectively. The properties of AC, XC and CC are studied by FTIR, XPS and SEM analysis.

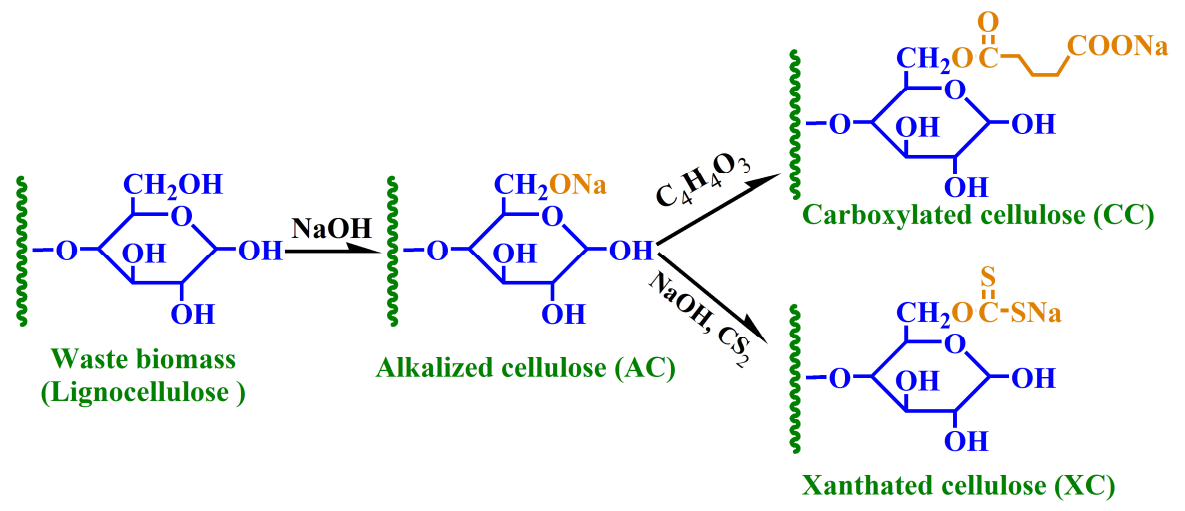

Figure 1. Preparation of functionalized lignocellulose from waste biomass.

In Figure 2a, characteristic peaks of AC, XC and CC are observed in FTIR spectra. The broad peak at $3426 \mathrm{~cm}^{-1}$ attributes to stretching vibrations of -OH. The peaks at 2851 and $2920 \mathrm{~cm}^{-1}$ assign to asymmetric and symmetric vibrations of $-\mathrm{CH}_{2}$ groups [27]. The peaks at 1000-1200 and $1635 \mathrm{~cm}^{-1}$ are due to vibrations of $\mathrm{C}-\mathrm{O}$ and $\mathrm{C}=\mathrm{O}$ bonds [28]. As to $\mathrm{XC}, \mathrm{C}=\mathrm{S}$ and $\mathrm{C}-\mathrm{S}$ groups are determined by the peaks at 582 and $1024 \mathrm{~cm}^{-1}$, verifying the creation of xanthate groups after xanthation modification [22]. As to CC, the peak at $1735 \mathrm{~cm}^{-1}$ corresponds to $\mathrm{C}=\mathrm{O}$ groups, revealing the presence of carboxyl groups after carboxylation modification. FTIR analysis manifests the introduction of more surface groups through modifications.

As shown in Figure 2b, the XPS survey spectra show that major elements of AC, XC and $C C$ are carbon and oxygen, which agrees well with the major ingredients of cellulose. The increase of sulfur content in XC and high resolution S2p spectra verify the presence of xanthate groups [22]. After carboxylation, the $\mathrm{O} / \mathrm{C}$ ratio increases from 0.1880 to 0.3367 , implying that more carboxyl groups are introduced on the surface. SEM micrograph of $X C$ and $C C$ is similar to that of $A C$, showing the porous and uneven surface morphology. Additionally, XC and CC have more pore structures, which favor metal sorption [14]. 

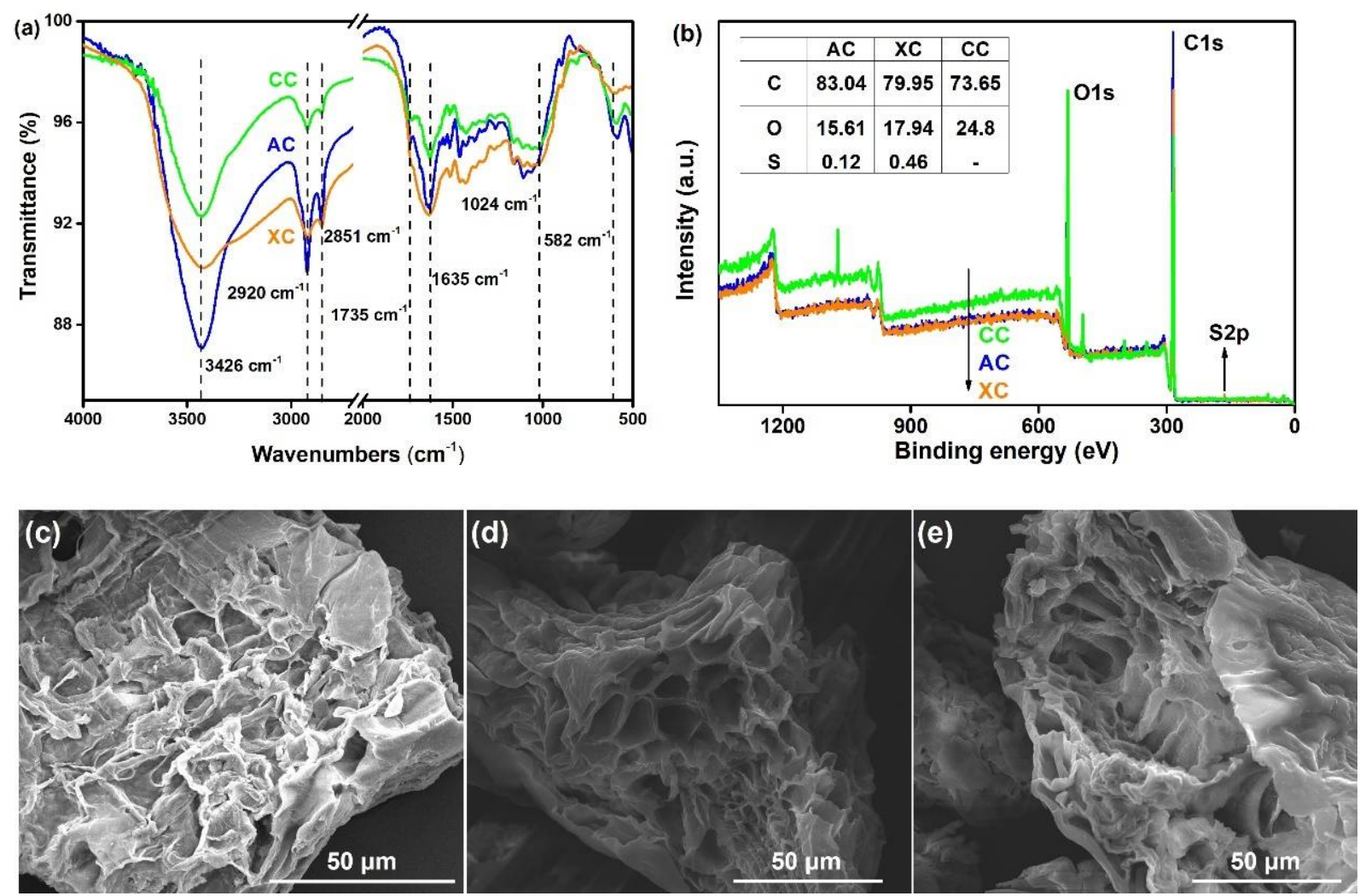

Figure 2. (a) FTIR spectra, (b) XPS survey spectra and (c-e) SEM morphology of AC, XC and CC.

\subsection{Sorption Studies}

\subsubsection{Effect of Sorbent Dosage on Zn(II) Sorption}

In Figure 3, the sorption capacity of $\mathrm{Zn}(\mathrm{II})$ onto $\mathrm{AC}, \mathrm{XC}$ and $\mathrm{CC}$ reduces with an increase of sorbent dosage. The phenomena can be attributed to unsaturation sorption and particle aggregation [18]. On the contrary, the removal rate increases significantly with increasing AC, XC and CC dosage, which attributes to more sorption sites derived from more sorbents [14]. The sorption behavior is consistent with $\mathrm{Zn}$ (II) sorption onto modified lemon grass [17]. Taking sorption capacity and removal rate into consideration, the optimal dosages for $\mathrm{Zn}(\mathrm{II})$ sorption are chosen as $24 \mathrm{~g} / \mathrm{L}$ AC, $12 \mathrm{~g} / \mathrm{L} \mathrm{XC}$ and $12 \mathrm{~g} / \mathrm{L}$ $\mathrm{CC}$, respectively.

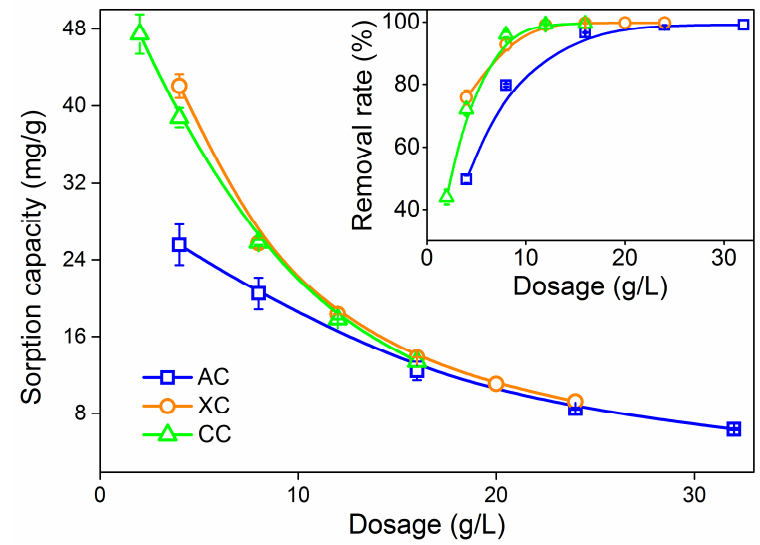

Figure 3. Effect of sorbent dosage on $\mathrm{Zn}$ (II) sorption (experimental conditions: $\mathrm{pH} 5.5 \pm 0.2$, sorption time $30 \mathrm{~min}$ and $\mathrm{Zn}$ (II) concentration $200 \mathrm{mg} / \mathrm{L}$ ). 


\subsubsection{Effect of Solution $\mathrm{Ph}$ on $\mathrm{Zn}(\mathrm{II})$ Sorption}

Solution $\mathrm{pH}$ affects metal species in aqueous solution and functional groups on sorbent surface [29]. Figure 4 shows that $\mathrm{Zn}$ (II) free ions are the predominant species in aqueous solution at $\mathrm{pH}$ below 7 [30]. The effect of solution $\mathrm{pH}$ on $\mathrm{Zn}$ (II) sorption is examined at $\mathrm{pH}$ below 7 , and alkaline solution is not used to avoid the formation of hydroxide precipitation. Figure 5 reveals that $\mathrm{Zn}(\mathrm{II})$ sorption is dependent on solution $\mathrm{pH}$. The sorption capacity and removal rate increase with an increase of $\mathrm{pH}$, especially at $\mathrm{pH}$ below 3.5. The results are similar to the study reported by Nasernejad et al. [31].

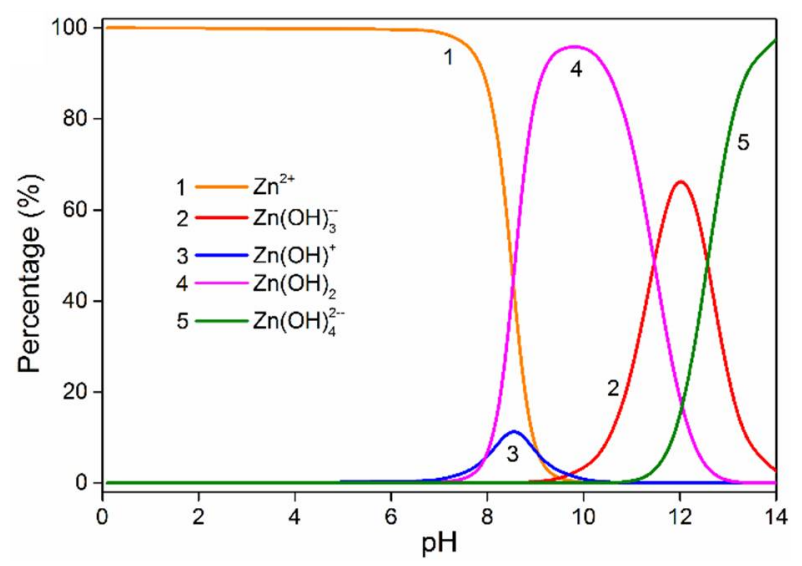

Figure 4. Zn species in aqueous solution at different $\mathrm{pH}$ (calculated by Visual MINTEQ 3.1).

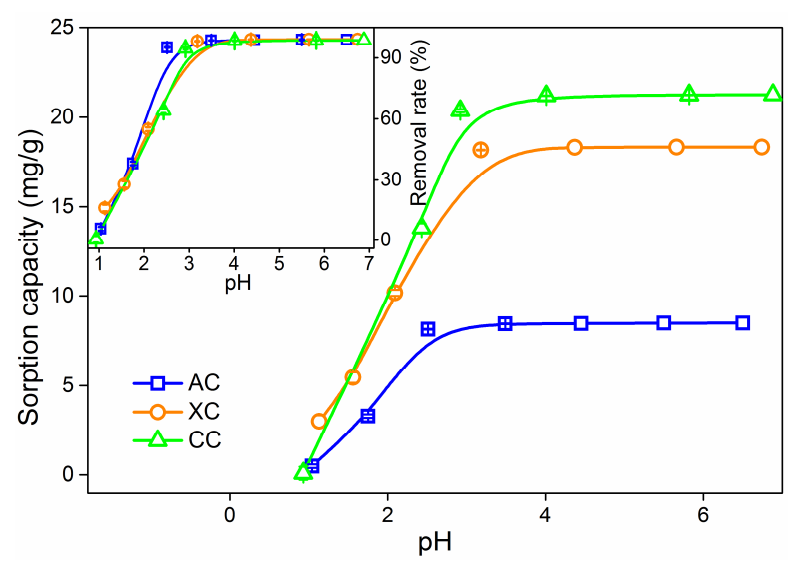

Figure 5. Effect of solution $\mathrm{pH}$ on $\mathrm{Zn}$ (II) sorption (experimental conditions: AC $24 \mathrm{~g} / \mathrm{L}, \mathrm{XC} 12 \mathrm{~g} / \mathrm{L}$, CC $12 \mathrm{~g} / \mathrm{L}$, sorption time $30 \mathrm{~min}$ and $\mathrm{Zn}$ (II) concentration $200 \mathrm{mg} / \mathrm{L}$ ).

In sorption process, besides surface complexation, ion exchange may occur due to the negatively charged oxygen or sulfur atoms $\left(-\mathrm{O}^{-} \mathrm{Na}^{+},-\mathrm{COO}^{-} \mathrm{Na}^{+}\right.$and $\left.-\mathrm{CSS}^{-} \mathrm{Na}^{+}\right)$[22]. At low $\mathrm{pH}$, abundant $\mathrm{H}^{+}$or $\mathrm{H}_{3} \mathrm{O}^{+}$leads to protonation of surface groups, causing fewer sites being available for $\mathrm{Zn}(\mathrm{II})$ sorption. Additionally, the binding $\mathrm{H}^{+}$or $\mathrm{H}_{3} \mathrm{O}^{+}$ions restricts the approach of $\mathrm{Zn}$ (II) cations by electrostatic repulsion [32]. It is expected that there is a competition between $\mathrm{H}^{+}$or $\mathrm{H}_{3} \mathrm{O}^{+}$and $\mathrm{Zn}$ (II) ions for the free sorption sites at low $\mathrm{pH}$. By contrast, CC has higher sorption capacity and is more sensitive to solution $\mathrm{pH}$. The difference in sorption behavior of $\mathrm{Zn}$ (II) onto $\mathrm{AC}, \mathrm{XC}$ and $\mathrm{CC}$ is mainly ascribed to the functional groups.

\subsubsection{Effect of Sorption Time on Zn(II) Sorption}

In Figure 6, the sorption capacity and removal rate of $\mathrm{Zn}(\mathrm{II})$ increase sharply with increasing sorption time at the initial stage, mainly attributing to abundant vacant sorption sites on sorbent surface. Sorption equilibrium is achieved at sorption time over $30 \mathrm{~min}$ due to saturation sorption. Compared with other reports [33,34], Zn(II) sorption in this work 
is faster. At equilibrium, the removal rate of $\mathrm{Zn}$ (II) onto $\mathrm{AC}, \mathrm{XC}$ and $\mathrm{CC}$ is $99.04 \pm 0.3 \%$, $99.20 \pm 0.4 \%$ and $98.68 \pm 0.9 \%$, respectively. The larger sorption capacity of XC and CC proves that xanthation and carboxylation modifications improve the performance for $\mathrm{Zn}(\mathrm{II})$ sorption.

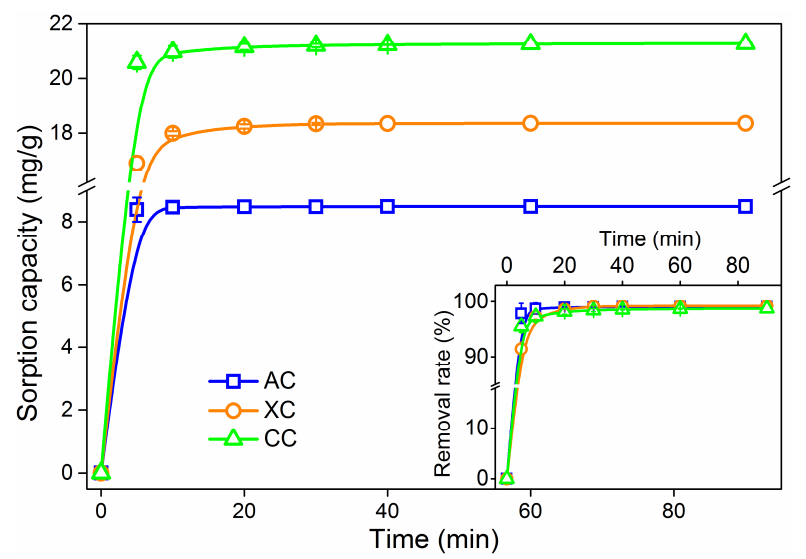

Figure 6. Effect of sorption time on Zn(II) sorption (AC 24 g/L, XC 12 g/L, CC 12 g/L, pH $5.5 \pm 0.2$, and $\mathrm{Zn}$ (II) concentration $200 \mathrm{mg} / \mathrm{L}$ ).

\subsubsection{Effect of Initial Concentration on Zn(II) Sorption}

The effect of initial $\mathrm{Zn}$ (II) concentration on sorption process is shown in Figure 7. The sorption capacity rises remarkably with increasing initial concentration. The concentration gradient provides the driving force for overcoming diffusion resistances of $\mathrm{Zn}(\mathrm{II})$ ions [29]. At high concentration, the sorption sites on sorbent surface are made full use for $\mathrm{Zn}$ (II) uptake, and thus the sorption capacity gradually reaches a plateau due to saturation sorption [30]. The removal rate drops significantly with increasing Zn(II) concentration. By contrast, $\mathrm{CC}$ shows higher sorption capacity at high concentration, which can be due to the presence of abundant carboxyl groups. For a given dosage, AC, XC and CC are suitable for managing wastewater with low $\mathrm{Zn}(\mathrm{II})$ concentration.

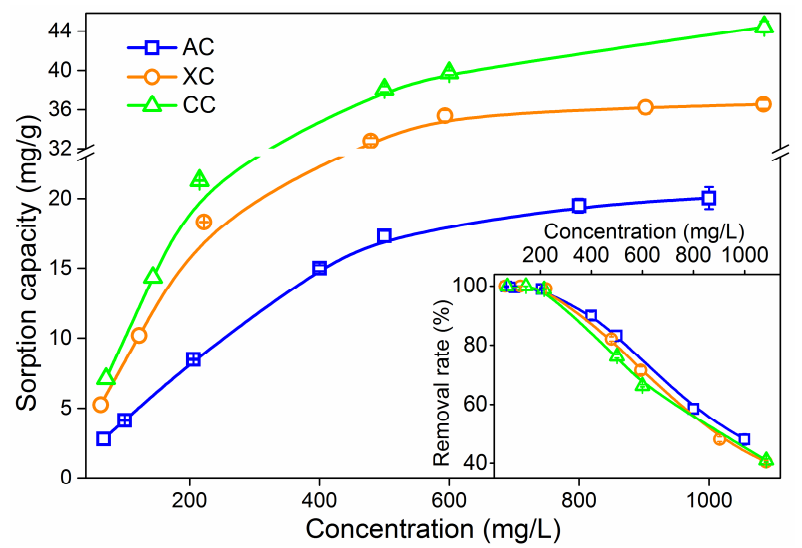

Figure 7. Effect of initial concentration on Zn(II) sorption (AC $24 \mathrm{~g} / \mathrm{L}, \mathrm{XC} 12 \mathrm{~g} / \mathrm{L}, \mathrm{CC} 12 \mathrm{~g} / \mathrm{L}$, pH $5.5 \pm 0.2$, and sorption time $30 \mathrm{~min}$ ).

\subsection{Sorption Kinetics}

Sorption kinetics is studied by pseudo first order (PFO), pseudo second order (PSO) and intraparticle diffusion (IPD) models [35-37]. The parameters for kinetics models are listed in Table 1. The correlation coefficients suggest that PFO and IPD models cannot describe the sorption process, especially for IPD model. This indicates that $\mathrm{Zn}$ (II) sorption is not controlled by internal diffusion. Figure 8a shows that PSO model exhibits well-fitting of sorption data. The rate constant of PSO model manifests that $\mathrm{Zn}$ (II) sorption onto AC is 
faster than that onto XC and CC. Generally, HMs sorption in aqueous solution involves (i) bulk diffusion, solute diffuses from the bulk solution to the liquid film surrounding sorbent surface; (ii) film diffusion, solute transports from the liquid film to sorbent surface; (iii) internal diffusion, solute moves from the surface to active intra-sites, and (iv) interactions between solute and sorption sites on internal surfaces [36]. One or more steps dominate metal sorption onto porous sorbents, and generally bulk diffusion is fast. The sorption behavior as a function of sorption time suggests that $\mathrm{Zn}$ (II) sorption onto AC, XC and $\mathrm{CC}$ is fast.

Table 1. Parameters for sorption kinetics.

\begin{tabular}{|c|c|c|c|c|c|c|c|c|c|}
\hline \multirow{2}{*}{ Sorbents } & \multicolumn{3}{|c|}{ PFO Model } & \multicolumn{3}{|c|}{ PSO Model } & \multicolumn{3}{|c|}{ IPD Model } \\
\hline & $Q_{e}(\mathrm{mg} / \mathrm{g})$ & $k_{1}\left(\min ^{-1}\right)$ & $\mathbf{R}^{2}$ & $Q_{e}(\mathrm{mg} / \mathrm{g})$ & $k_{2}(\mathrm{~g} /(\mathrm{mg} \min ))$ & $\mathbf{R}^{2}$ & $C$ & $k_{i}$ & $\mathbf{R}^{2}$ \\
\hline AC & 0.0566 & 0.0596 & 0.8982 & 8.4947 & 3.5262 & 1.0 & 8.4083 & 0.0109 & 0.4656 \\
\hline $\mathrm{XC}$ & 0.7183 & 0.0861 & 0.8923 & 18.4060 & 0.2934 & 1.0 & 17.2527 & 0.1486 & 0.4151 \\
\hline $\mathrm{CC}$ & 0.5192 & 0.0553 & 0.9580 & 21.2811 & 0.4029 & 1.0 & 20.6397 & 0.0795 & 0.6050 \\
\hline
\end{tabular}
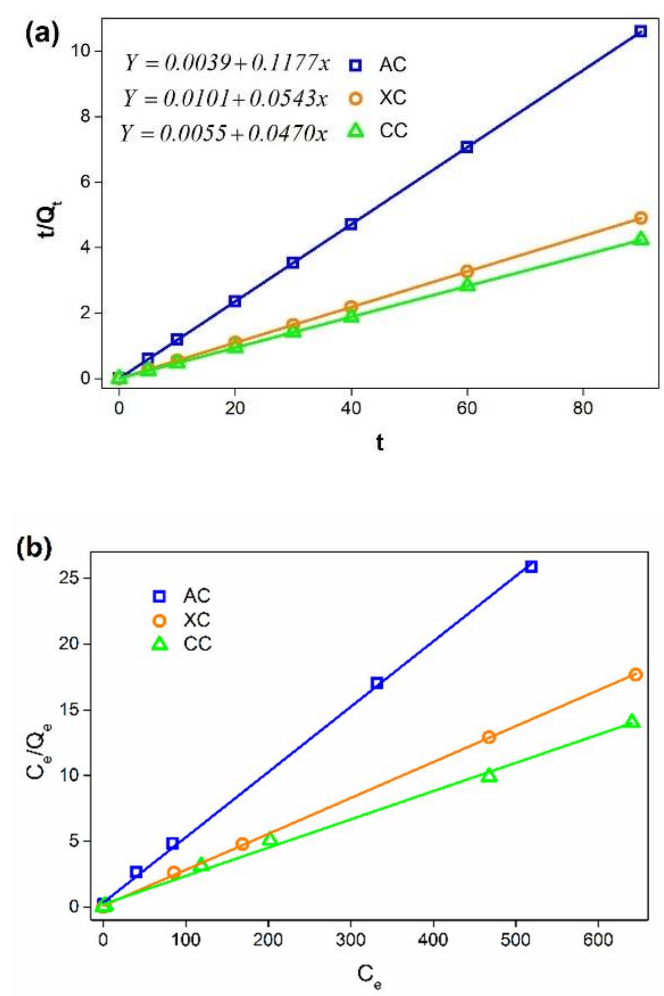

Figure 8. (a) PSO kinetics plots and (b) Langmuir isotherms for $\mathrm{Zn}(\mathrm{II})$ sorption onto AC, XC and CC.

Mechanism for HMs adsorption generally involves physical adsorption, ion exchange, surface precipitation, surface complexation and electrostatic interaction [38]. The porous structure of $\mathrm{AC}, \mathrm{XC}$ and $\mathrm{CC}$ is mainly derived from raw biomass, and thus physical adsorption due to porous structure contributes little to $\mathrm{Zn}$ (II) sorption. Due to the functional groups caused by modifications, $\mathrm{Zn}$ (II) sorption onto XC and CC can be explained by surface complexation or ion exchange. The well-fitting PSO reveals that $\mathrm{Zn}(\mathrm{II})$ sorption onto $\mathrm{AC}, \mathrm{XC}$ and $\mathrm{CC}$ is dominated by chemisorption that involves transferring or sharing of electrons [27,32].

\subsection{Sorption Isotherms}

$\mathrm{Zn}$ (II) sorption onto AC, XC and CC is examined by Langmuir and Freundlich isotherms (Wang et al., 2018a). Parameters for Langmuir and Freundlich models are shown in Table 2. The sorption process can be well described by Langmuir and Freundlich models. The Freundlich parameter, $n(2<n<10)$, reveals that $\mathrm{Zn}$ (II) sorption on the sor- 
bents is favorable. Figure $8 \mathrm{~b}$ shows good linear fitting to sorption data by Langmuir model. Owing to high correlation coefficient and consistency between calculated and experimental values of $Q_{m}, \mathrm{Zn}(\mathrm{II})$ sorption onto $\mathrm{AC}, \mathrm{XC}$ and $\mathrm{CC}$ follows Langmuir isotherm.

Table 2. Parameters for sorption isotherms.

\begin{tabular}{|c|c|c|c|c|c|c|c|}
\hline \multirow[b]{2}{*}{ Sorbents } & \multicolumn{3}{|c|}{ Langmuir Model } & \multicolumn{3}{|c|}{ Freundlich Model } & \multirow[b]{2}{*}{$Q_{m, \exp }(\mathrm{mg} / \mathrm{g})$} \\
\hline & $Q_{m}(\mathrm{mg} / \mathrm{g})$ & $b(\mathrm{~L} / \mathrm{mg})$ & $\mathbf{R}^{2}$ & $\begin{array}{c}K_{F} \\
(\mathrm{mg} / \mathrm{g}) /(\mathrm{mg} / \mathrm{L})^{1 / n}\end{array}$ & $n$ & $\mathbf{R}^{2}$ & \\
\hline $\mathrm{AC}$ & 20.1248 & 0.1544 & 0.9990 & 5.4587 & 4.2439 & 0.9445 & 20.04 \\
\hline $\mathrm{XC}$ & 36.5898 & 0.2979 & 0.9998 & 14.3757 & 6.0890 & 0.9491 & 36.54 \\
\hline $\mathrm{CC}$ & 46.4912 & 0.1030 & 0.9960 & 15.9181 & 5.8889 & 0.8988 & 47.10 \\
\hline
\end{tabular}

Langmuir model is based on these assumptions: monolayer adsorption, homogeneous sorption sites, initially free sites, ideal behavior of surface and bulk phases and equal molar surface areas of solute and solvent [39]. Langmuir constant, b, relates to the bond energy of sorption reaction between metal ion and sorbent [40]. It is a simple fitting parameter rather than Langmuir sorption constant since the system does not meet with all the assumptions of Langmuir model [41]. However, $\mathrm{b}$ is useful to determine the sorption affinity of sorbents. $\mathrm{XC}$ shows larger $\mathrm{b}$ value for $\mathrm{Zn}(\mathrm{II})$ sorption, suggesting the bond energy between ligands of XC and $\mathrm{Zn}$ (II) is larger than CC. This can be explained by different ligands of XC and $\mathrm{CC}$, namely $-\mathrm{CSS}^{-}$and $-\mathrm{COO}^{-}$.

The maximum sorption capacity of $\mathrm{Zn}(\mathrm{II})$ onto unmodified biomass is $12.39 \mathrm{mg} / \mathrm{g}$, and modifications obviously improve the sorption capacity. CC and XC is 2.3 and 1.8 times higher than that onto AC, implying that functionalized lignocellulose remarkably enhances $\mathrm{Zn}$ (II) sorption. The higher sorption capacity onto CC is related to abundant carboxyl groups on CC indicated by high oxygen content. Due to the difference in experimental materials, methods and conditions, direct comparison of sorption capacity from different reports is difficult. As listed in Table 3, the sorption capacity of $\mathrm{Zn}$ (II) onto CC is higher than that of other sorbents. It should be noted that process cost and sorption efficiency should be considered for removal HMs using LCB.

Table 3. Maximum capacity for $\mathrm{Zn}(\mathrm{II})$ sorption onto different sorbents.

\begin{tabular}{|c|c|c|c|c|c|c|}
\hline Sorbents & References & $\begin{array}{c}\text { Capacity } \\
\text { (mg/g) }\end{array}$ & Solution $\mathrm{pH}$ & $\begin{array}{c}\text { Sorption Time } \\
\text { (min) }\end{array}$ & $\begin{array}{c}\text { Initial Concentration } \\
(\mathrm{mg} / \mathrm{L})\end{array}$ & $\begin{array}{c}\text { Temperature } \\
\left({ }^{\circ} \mathrm{C}\right)\end{array}$ \\
\hline Lemon grass & [17] & 15.87 & 6.0 & 180 & 10 & 25 \\
\hline Carrot residues & [31] & 29.61 & 4.5 & 1440 & $20-500$ & 25 \\
\hline Tectona grandis & [33] & 16.42 & 5.0 & 180 & 20 & 30 \\
\hline $\begin{array}{l}\text { Spirodela } \\
\text { polyrhiza }\end{array}$ & [34] & 28.50 & 6.0 & 120 & $5-35$ & 30 \\
\hline $\begin{array}{l}\text { Corn straw } \\
\text { biochar }\end{array}$ & [42] & 11.00 & 5.0 & 1440 & $6-260$ & 22 \\
\hline $\begin{array}{l}\text { Hardwood } \\
\text { biochar }\end{array}$ & [42] & 4.54 & 5.0 & 1440 & $6-260$ & 22 \\
\hline $\begin{array}{c}\text { Coconut } \\
\text { shell-based } \\
\text { activated carbon }\end{array}$ & [43] & 9.43 & 7.0 & 1200 & $5-50$ & 32 \\
\hline Fallen leaves & This study & 12.39 & 6.0 & 30 & 50-1000 & 30 \\
\hline $\mathrm{AC}$ & This study & 20.12 & 6.0 & 30 & $50-1000$ & 30 \\
\hline $\mathrm{XC}$ & This study & 36.59 & 6.0 & 30 & $50-1000$ & 30 \\
\hline CC & This study & 46.49 & 6.0 & 30 & $50-1000$ & 30 \\
\hline
\end{tabular}

\subsection{Sorption Thermodynamics}

The calculated Gibbs free energy change $(\Delta G)$, enthalpy change $(\Delta H)$ and entropy change $(\Delta S)$ for $\mathrm{Zn}(\mathrm{II})$ sorption are displayed in Table 4 . The negative value of Gibbs free energy change suggests that $\mathrm{Zn}$ (II) sorption onto $\mathrm{AC}, \mathrm{XC}$ and $\mathrm{CC}$ is spontaneous [44]. $\mathrm{Zn}$ (II) sorption onto $\mathrm{AC}$ and $\mathrm{CC}$ is exothermic due to $\Delta H<0$, revealing that increasing temperature goes against $\mathrm{Zn}$ (II) sorption [33]. However, it is endothermic for $\mathrm{Zn}$ (II) sorption onto XC owing to the positive value of $\Delta H$. The negative values of $\Delta S$ for $\mathrm{Zn}$ (II) sorption 
onto $\mathrm{AC}$ and $\mathrm{CC}$ manifests that the adsorbed $\mathrm{Zn}(\mathrm{II})$ ions are more ordered than $\mathrm{Zn}(\mathrm{II})$ ions near sorbent surface. As indicated by the positive value of $\Delta S, \mathrm{Zn}$ (II) sorption onto $X C$ decreases the randomness at the solid-solution interface [33]. The difference in $\mathrm{Zn}(\mathrm{II})$ sorption onto CC and XC can be explained by different binding model between $\mathrm{Zn}$ (II) and surface groups containing oxygen or sulfur. Combined with analysis of sorption kinetics, isotherms and thermodynamics, it can be concluded that CC is very promising for $\mathrm{Zn}$ (II) sorption with respect to wastewater treatment.

Table 4. Thermodynamic parameters for Zn(II) sorption onto AC, XC and CC.

\begin{tabular}{|c|c|c|c|c|c|c|}
\hline \multirow{2}{*}{ Sorbents } & \multicolumn{3}{|c|}{$\Delta G(\mathrm{~kJ} / \mathrm{mol})$} & \multirow{2}{*}{$\Delta S(\mathrm{~J} /(\mathrm{mol} \cdot \mathrm{K}))$} & \multirow{2}{*}{$\Delta H(\mathrm{~kJ} / \mathrm{mol})$} & \multirow{2}{*}{$\mathbf{R}^{2}$} \\
\hline & $303 \mathrm{~K}$ & $313 \mathrm{~K}$ & $323 \mathrm{~K}$ & & & \\
\hline $\mathrm{AC}$ & -3.5171 & -3.3848 & -3.2856 & -11.6121 & -7.0304 & 0.9964 \\
\hline$X C$ & -5.6069 & -6.0788 & -6.4772 & 43.5929 & 7.5903 & 0.9849 \\
\hline $\mathrm{CC}$ & -5.5008 & -4.3984 & -3.6653 & -92.1694 & -33.3705 & 0.9802 \\
\hline
\end{tabular}

\section{Conclusions}

Waste biomass was modified by alkalization, xanthation and carboxylation for $\mathrm{Zn}$ (II) sorption. FTIR and XPS verify the introduction of functional groups on sorbent surface, and SEM show porous structure of sorbents. $\mathrm{Zn}$ (II) sorption is highly dependent on process parameters including sorbent dosage, solution $\mathrm{pH}$, sorption time and $\mathrm{Zn}$ (II) concentration. The sorption capacity of $\mathrm{Zn}(\mathrm{II})$ onto $\mathrm{AC}, \mathrm{XC}$ and $\mathrm{CC}$ declines with an increase of sorbent dosage and $\mathrm{Zn}$ (II) concentration and increases with increasing solution $\mathrm{pH}$ and sorption time. Optimal parameters of $\mathrm{Zn}$ (II) sorption are obtained considering sorption capacity and removal rate. The sorption process obeys PSO kinetic model and Langmuir isotherm. Maximum sorption capacity of Zn(II) onto AC, XC and CC is 20.12, 36.59 and $46.49 \mathrm{mg} / \mathrm{g}$, respectively. $\mathrm{Zn}$ (II) sorption onto $\mathrm{CC}$ is fast and spontaneous, and the sorption capacity is higher than other reported sorbents. Sorption mechanism is majorly attributed to surface complexation. This work reveals the enhancement of $\mathrm{Zn}$ (II) sorption by functionalized cellulose, providing effective modifications of LCB for preparation of sorbents. Additionally, conversion of locally available waste biomass into sorbents of HMs will find promising application in China.

Author Contributions: Conceptualization, H.W. and C.W.; methodology, C.W.; software, J.D.; validation, J.D., H.W. and C.W.; investigation, C.W.; writing—original draft preparation, J.D.; writingreview and editing, C.W.; project administration, H.W.; funding acquisition, J.D. and C.W. All authors have read and agreed to the published version of the manuscript.

Funding: This research was funded by the National Key R\&D Program of China, grant number 2020YFC1908802; the Department of Science and Technology of Henan Province, China, grant number 192102110197.

Institutional Review Board Statement: Not applicable.

Informed Consent Statement: Not applicable.

Data Availability Statement: Data available on request due to restrictions of privacy.

Acknowledgments: This work acknowledged the Excellent Youth Scientist of China Association for Science and Technology.

Conflicts of Interest: The authors declare no conflict of interest.

\section{References}

1. Guo, J.; Kang, Y.; Feng, Y. Bioassessment of heavy metal toxicity and enhancement of heavy metal removal by sulfate-reducing bacteria in the presence of zero valent iron. J. Environ. Manag. 2017, 203, 278-285. [CrossRef]

2. Shahid, M.; Dumat, C.; Khalid, S.; Schreck, E.; Xiong, T.; Niazi, N.K. Foliar heavy metal uptake, toxicity and detoxification in plants: A comparison of foliar and root metal uptake. J. Hazard. Mater. 2017, 325, 36-58. [CrossRef] [PubMed] 
3. Oulguidoum, A.; Bouyarmane, H.; Laghzizil, A.; Nunzi, J.M.; Saoiabi, A. Development of sulfonate-functionalized hydroxyapatite nanoparticles for cadmium removal from aqueous solutions. Colloid Interface Sci. Commun. 2019, 30, 100178. [CrossRef]

4. Yu, G.; Wang, X.; Liu, J.; Jiang, P.; You, S.; Ding, N.; Lin, F. Applications of nanomaterials for heavy metal removal from water and soil: A review. Sustainability 2021, 13, 713. [CrossRef]

5. Wang, C.; Wang, $\mathrm{H}$. Pb(II) sorption from aqueous solution by novel biochar loaded with nano-particles. Chemosphere 2018, 192, 1-4. [CrossRef]

6. Abbas, A.; Al-Amer, A.M.; Laoui, T.; Al-Marri, M.J.; Nasser, M.S.; Khraisheh, M.; Atieh, M.A. Heavy metal removal from aqueous solution by advanced carbon nanotubes: Critical review of adsorption applications. Sep. Purif. Technol. 2016, 157, 141-161.

7. Sherlala, A.I.A.; Raman, A.A.A.; Bello, M.M.; Asghar, A. A review of the applications of organo-functionalized magnetic graphene oxide nanocomposites for heavy metal adsorption. Chemosphere 2018, 193, 1004-1017. [CrossRef]

8. Kolbasov, A.; Sinha-Ray, S.; Yarin, A.L.; Pourdeyhimi, B. Heavy metal adsorption on solution-blown biopolymer nanofiber membranes. J. Membr. Sci. 2017, 530, 250-263. [CrossRef]

9. Deliyanni, E.A.; Kyzas, G.Z.; Triantafyllidis, K.S.; Matis, K.A. Activated carbons for the removal of heavy metal ions: A systematic review of recent literature focused on lead and arsenic ions. Open Chem. 2015, 13, 699-708. [CrossRef]

10. Karri, R.R.; Sahu, J.N.; Meikap, B.C. Improving efficacy of Cr (VI) adsorption process on sustainable adsorbent derived from waste biomass (sugarcane bagasse) with help of ant colony optimization. Ind. Crop. Prod. 2020, 143, 111927. [CrossRef]

11. Saravanan, A.; Sundararaman, T.R.; Jeevanantham, S.; Karishma, S.; Kumar, P.S.; Yaashikaa, P.R. Effective adsorption of Cu(II) ions on sustainable adsorbent derived from mixed biomass (Aspergillus campestris and agro waste): Optimization, isotherm and kinetics study. Groundw. Sustain. Dev. 2020, 11, 100460. [CrossRef]

12. Lee, S.Y.; Choi, H.J. Persimmon leaf bio-waste for adsorptive removal of heavy metals from aqueous solution. J. Environ. Manag. 2018, 209, 382-392. [CrossRef] [PubMed]

13. Tang, J.; Li, Y.; Wang, X.; Daroch, M. Effective adsorption of aqueous Pb2+ by dried biomass of Landoltia punctata and Spirodela polyrhiza. J. Clean. Prod. 2017, 145, 25-34. [CrossRef]

14. Wang, C.; Wang, H.; Gu, G.; Liu, Y. Sorption of Cd(II) ion by lignocellulose biomass from leaves of camphor tree. Desalination Water Treat. 2017, 68, 211-219. [CrossRef]

15. Das, D.; Das, N. Optimization of parameters for praseodymium(III) biosorption onto biowaste materials using response surface methodology: Equilibrium, kinetic and regeneration studies. Ecol. Eng. 2015, 81, 321-327.

16. Ngah, W.W.; Hanafiah, M.A.K.M. Removal of heavy metal ions from wastewater by chemically modified plant wastes as adsorbents: A review. Bioresour. Technol. 2008, 99, 3935-3948. [CrossRef]

17. Zuo, X.; Balasubramanian, R.; Fu, D.; Li, H. Biosorption of copper, zinc and cadmium using sodium hydroxide immersed Cymbopogon schoenanthus L. Spreng (lemon grass). Ecol. Eng. 2012, 49, 186-189. [CrossRef]

18. Ma, J.; Jia, Y.; Jing, Y.; Yao, Y.; Sun, J. Kinetics and thermodynamics of methylene blue adsorption by cobalt-hectorite composite. Dye. Pigment. 2012, 93, 1441-1446. [CrossRef]

19. Ronda, A.; Calero, M.; Blázquez, G.; Pérez, A.; Martín-Lara, M.A. Optimization of the use of a biosorbent to remove heavy metals: Regeneration and reuse of exhausted biosorbent. J. Taiwan Inst. Chem. Eng. 2015, 51, 109-118. [CrossRef]

20. Madala, S.; Mudumala, V.N.R.; Vudagandla, S.; Abburi, K. Modified leaf biomass for Pb(II) removal from aqueous solution: Application of response surface methodology. Ecol. Eng. 2015, 83, 218-226. [CrossRef]

21. Du, Z.; Zheng, T.; Wang, P.; Hao, L.; Wang, Y. Fast microwave-assisted preparation of a low-cost and recyclable carboxyl modified lignocellulose-biomass jute fiber for enhanced heavy metal removal from water. Bioresour. Technol. 2016, 201, 41-49. [CrossRef] [PubMed]

22. Wang, C.; Wang, H.; Gu, G. Ultrasound-assisted xanthation of cellulose from lignocellulosic biomass optimized by response surface methodology for Pb(II) sorption. Carbohydr. Polym. 2018, 182, 21-28. [CrossRef] [PubMed]

23. Hojati, S.; Landi, A. Kinetic and Thermodynamic Studies of Zinc Removal from a Metal-Plating Wastewater Using Firouzkouh Zeolite. J. Environ. Stud. 2015, 40, 15-16.

24. Demirbas, A. Heavy metal adsorption onto agro-based waste materials: A review. J. Hazard. Mater. 2008, 157, 220-229. [CrossRef]

25. Gurgel, L.V.A.; Freitas, R.P.D.; Gil, L.F. Adsorption of $\mathrm{Cu}(\mathrm{II}), \mathrm{Cd}(\mathrm{II})$, and $\mathrm{Pb}(\mathrm{II})$ from aqueous single metal solutions by sugarcane bagasse and mercerized sugarcane bagasse chemically modified with succinic anhydride. Carbohydr. Polym. 2008, 74, 922-929. [CrossRef]

26. Wang, C.; Wang, H.; Liu, Y. Purification of $\mathrm{Pb}(\mathrm{II})$ ions from aqueous solution by camphor leaf modified with succinic anhydride. Colloids Surf. A Physicochem. Eng. Asp. 2016, 509, 80-85. [CrossRef]

27. Wang, C.; Wang, H. Carboxyl functionalized Cinnamomum camphora for removal of heavy metals from synthetic wastewatercontribution to sustainability in agroforestry. J. Clean. Prod. 2018, 184, 921-928. [CrossRef]

28. Wang, C.; Sun, R.; Huang, R. Highly dispersed iron-doped biochar derived from sawdust for Fenton-like degradation of toxic dyes. J. Clean. Prod. 2021, 297, 126681. [CrossRef]

29. Zhu, H.X.; Cao, X.J.; He, Y.C.; Kong, Q.P.; He, H.; Wang, J. Removal of $\mathrm{Cu}^{2+}$ from aqueous solutions by the novel modified bagasse pulp cellulose: Kinetics, isotherm and mechanism. Carbohydr. Polym. 2015, 129, 115-126. [CrossRef]

30. Cho, H.H.; Wepasnick, K.; Smith, B.A.; Bangash, F.K.; Fairbrother, D.H.; Ball, W.P. Sorption of aqueous Zn [II] and Cd [II] by multiwall carbon nanotubes: The relative roles of oxygen-containing functional groups and graphenic carbon. Langmuir 2009, 26, 967-981. [CrossRef] 
31. Nasernejad, B.; Zadeh, T.E.; Pour, B.B.; Bygi, M.E.; Zamani, A. Camparison for biosorption modeling of heavy metals (Cr(III), $\mathrm{Cu}(\mathrm{II}), \mathrm{Zn}(\mathrm{II}))$ adsorption from wastewater by carrot residues. Process. Biochem. 2005, 40, 1319-1322. [CrossRef]

32. Zeng, G.; Liu, Y.; Tang, L.; Yang, G.; Pang, Y.; Zhang, Y.; He, X. Enhancement of Cd(II) adsorption by polyacrylic acid modified magnetic mesoporous carbon. Chem. Eng. J. 2015, 259, 153-160. [CrossRef]

33. Kumar, Y.P.; King, P.; Prasad, V.S.R.K. Zinc biosorption on Tectona grandis Lf leaves biomass: Equilibrium and kinetic studies. Chem. Eng. J. 2006, 124, 63-70. [CrossRef]

34. Meitei, M.D.; Prasad, M.N.V. Adsorption of $\mathrm{Cu}(\mathrm{II}), \mathrm{Mn}(\mathrm{II})$ and $\mathrm{Zn}(\mathrm{II})$ by Spirodela polyrhiza (L.) Schleiden: Equilibrium, kinetic and thermodynamic studies. Ecol. Eng. 2014, 71, 308-317. [CrossRef]

35. Wang, C.; Wang, H.; Cao, Y. Pb(II) sorption by biochar derived from Cinnamomum camphora and its improvement with ultrasound-assisted alkali activation. Colloids Surf. A Physicochem. Eng. Asp. 2018, 556, 177-184. [CrossRef]

36. Argun, M.E.; Dursun, S.; Ozdemir, C.; Karatas, M. Heavy metal adsorption by modified oak sawdust: Thermodynamics and kinetics. J. Hazard. Mater. 2007, 141, 77-85. [CrossRef]

37. Simonin, J.P. On the comparison of pseudo-first order and pseudo-second order rate laws in the modeling of adsorption kinetics. Chem. Eng. J. 2016, 300, 254-263. [CrossRef]

38. Yang, X.; Wan, Y.; Zheng, Y.; He, F.; Yu, Z.; Huang, J.; Gao, B. Surface functional groups of carbon-based adsorbents and their roles in the removal of heavy metals from aqueous solutions: A critical review. Chem. Eng. J. 2019, 366, 608-621. [CrossRef]

39. Langmuir, I. The adsorption of gases on plane surfaces of glass, mica and platinum. J. Am. Chem. Soc. 1918, 40, 1361-1403. [CrossRef]

40. Wadhawan, S.; Jain, A.; Nayyar, J.; Mehta, S.K. Role of nanomaterials as adsorbents in heavy metal ion removal from waste water: A review. J. Water Process. Eng. 2020, 33, 101038. [CrossRef]

41. Gurgel, L.V.A.; Gil, L.F. Adsorption of $\mathrm{Cu}(\mathrm{II}), \mathrm{Cd}(\mathrm{II})$ and $\mathrm{Pb}(\mathrm{II})$ from aqueous single metal solutions by succinylated twicemercerized sugarcane bagasse functionalized with triethylenetetramine. Water Res. 2009, 43, 4479-4488. [CrossRef] [PubMed]

42. Chen, X.; Chen, G.; Chen, L.; Chen, Y.; Lehmann, J.; McBride, M.B.; Hay, A.G. Adsorption of copper and zinc by biochars produced from pyrolysis of hardwood and corn straw in aqueous solution. Bioresour. Technol. 2011, 102, 8877-8884. [CrossRef] [PubMed]

43. Shrestha, S.; Son, G.; Lee, S.H.; Lee, T.G. Isotherm and thermodynamic studies of Zn(II) adsorption on lignite and coconut shell-based activated carbon fiber. Chemosphere 2013, 92, 1053-1061. [CrossRef]

44. Ünlü, N.; Ersoz, M. Adsorption characteristics of heavy metal ions onto a low cost biopolymeric sorbent from aqueous solutions. J. Hazard. Mater. 2006, 136, 272-280. [CrossRef] [PubMed] 